\title{
Inventarisasi Jenis-jenis Tanaman Pekarangan dan Pemanfaatannya di Desa Tanjung Merpati Kecamatan Kembayan Kabupaten Sanggau
}

\author{
Ulul Maulina Riami ${ }^{1}$, Elvi Rusmiyanto ${ }^{1}$, Rafdinal $^{1}$ \\ ${ }^{1}$ Program Studi Biologi, Fakultas MIPA, Universitas Tanjungpura, Prof. Dr. H. Hadari Nawawi, Pontianak \\ email korespondensi: ululmaulina93@yahoo.com
}

\begin{abstract}
The yard is a plot of land located directly around the house of residence with clear boundaries, planted with one or various type of plants and still have ownership as well as functional relationship with the house concerned. This aims of this study to determine the species of yard plants and their use in Tanjung Merpati Village, Kembayan sub-district, Sanggau districts. The study was conducted from March to May 2017. Location determinations of the study was carried out by purposive random sampling methode which is based on the yard area category, namely large, medium and small categories. Acording to the research finding, there are 89 species of plants belonging to 4 Classes, 34 Orders, and 55 Families. The four classes of plants found were Magnoliopsida, Liliopsida, Gnetopsida and Cycadopsida. Based on the utilization of yard plants found in Tanjung Merpati Village, those plants are divided into 5 groups, namely ornamental plants, fruit plants, vegetable, medicinal plants and herbs.
\end{abstract}

Keywords: Yard, Species of plants, Tanjung Merpati Village, Inventory

\section{PENDAHULUAN}

Pekarangan adalah sebidang tanah yang terletak disekitar rumah dan biasanya dikelilingi pagar atau pembatas (Rukmana, 2005). Peranan dan pola pemanfaatan lahan pekarangan dari setiap wilayah bervariasi, tergantung pada kondisi sosial budaya, pendidikan, tingkat kebutuhan, ataupun ekologi setempat (Rahayu \& Prawiroatmodjo, 2005).

Desa Tanjung Merpati merupakan salah satu wilayah yang ada di Kecamatan Kembayan. Desa ini memiliki wilayah seluas 6.500 ha, dengan jumlah penduduk yang meningkat setiap tahunnya. Tahun 2015 penduduk Desa Tanjung Merpati tercatat sebanyak 64.210 jiwa, dan jumlahnya meningkat pada tahun 2016 yakni menjadi 64.757 jiwa (Monografi Desa, 2016). Mayoritas penduduk Desa Tanjung Merpati berprofesi sebagai petani, baik petani sayuran, buah-buahan dan yang lainnya. Selain bertani di lahan perkebunan yang cukup luas, tidak sedikit warga desa yang bercocok tanam di lahan pekarangan rumahnya.

Umumnya di Desa Tanjung Merpati, pekarangan ditanami tanaman buah-buahan dan hias, namun tidak sedikit yang menanam tanaman obat-obatan. Tanaman di pekarangan penduduk tidak hanya memberikan keindahan, namun juga berperan dalam pemenuhan kebutuhan sehari-hari dan meningkatkan pendapatan penduduk. Keanekaragaman tanaman pekarangan merupakan bagian dari keanekaragaman hayati yang mempunyai peran utama bagi kehidupan masyarakat, khususnya masyarakat pedesaan. Pemanfaatan lahan pekarangan yang tepat dapat memberikan berbagai macam manfaat yang bagi masyarakat. Hal inilah yang mendorong untuk dilakukannya penelitian ini.

Adapun tujuan dilakukannya penelitian ini adalah untuk mengetahui jenis-jenis tanaman pekarangan dan pemanfaatannya di Desa Tanjung Merpati Kecamatan Kembayan Kabupaten Sanggau.

\section{BAHAN DAN METODE}

\section{Waktu dan Tempat Penelitian}

Penelitian ini dilakukan selama 3 bulan, mulai dari bulan Maret sampai Mei 2017. Lokasi penelitian terletak di Desa Tanjung Merpati, Kecamatan Kembayan, Kabupaten Sanggau. Identifikasi dilakukan di Laboratorium Biologi Fakultas Matematika dan Ilmu Pengetahuan Alam Universitas Tanjungpura Pontianak.

\section{Deskripsi Lokasi}

Desa Tanjung Merpati memiliki wilayah dengan luas 6.500 ha atau sekitar 10,6\% dari luas wilayah Kecamatan Kembayan. Desa ini terdiri dari 7 dusun, yakni Dusun Seberang, Dusun Tanjung Merpati, Dusun Kuala, Dusun Keroyet, Dusun Pasar, Dusun Serambai, dan Dusun Tanjung Periuk. 


\section{Alat dan Bahan}

Alat yang digunakan dalam penelitian ini adalah alat tulis, hygrometer, kamera digital, meteran, soiltester, dan termometer.

\section{Metode Penelitian}

Penentuan lokasi penelitian dilakukan dengan metode purposive random sampling yakni berdasarkan kategori luas pekarangan. Menurut Menteri Pertanian (2016), berdasarkan luas lahan pekarangan dan pemanfaatannya, diperoleh 3 kategori luas pekarangan yaitu pekarangan sempit $\left(<100 \mathrm{~m}^{2}\right)$, pekarangan sedang $\left(100-300 \mathrm{~m}^{2}\right)$ dan pekarangan luas $\left(>300 \mathrm{~m}^{2}\right)$.

Terdapat 9 lokasi penelitian di setiap dusun, yaitu 3 lokasi untuk pekarangan sempit, 3 lokasi untuk pekarangan sedang dan 3 lokasi untuk pekarangan luas, sehingga total untuk keseluruhan lokasi penelitian adalah 7 × $9=63$ pekarangan. Pengambilan sampel dilakukan dengan observasi sampel langsung di pekarangan, dan jumlah ini diharapkan dapat mewakili gambaran secara umum mengenai pemanfaatan lahan pekarangan oleh penduduk Desa Tanjung Merpati.

\section{HASIL DAN PEMBAHASAN}

\section{Hasil}

Berdasarkan hasil penelitian diperoleh 89 jenis tanaman yang tersebar pada setiap kategori pekarangan yakni sempit, sedang dan luas. Jenisjenis tanaman pekarangan tersebut tergolong kedalam 4 kelas, 34 ordo dan 55 famili. Keempat kelas tanaman yang ditemukan adalah Kelas Magnoliopsida, Liliopsida, Gnetopsida dan Cycadopsida (Tabel 1).

Tabel 1. Klasifikasi Tanaman dan Letaknya pada Kategori Pekarangan di Desa Tanjung Merpati Kecamatan Kembayan Kabupaten Sanggau

\begin{tabular}{|c|c|c|c|c|c|c|c|}
\hline \multirow[t]{2}{*}{ No. } & \multirow[t]{2}{*}{ Kelas } & \multirow[t]{2}{*}{ Ordo } & \multirow[t]{2}{*}{ Famili } & \multirow[t]{2}{*}{ Spesies } & \multicolumn{3}{|c|}{$\begin{array}{c}\text { Kategori } \\
\text { Pekarangan }\end{array}$} \\
\hline & & & & & Luas & Sedang & Sempit \\
\hline 1 & 2 & 3 & 4 & 5 & 6 & 7 & 8 \\
\hline 1 & Magnoliopsida & Scrophulariales & Acanthaceae & Andrographis paniculata & + & & \\
\hline 2 & Magnoliopsida & Caryophyllales & Amaranthaceae & Celosia cristata & + & & \\
\hline 3 & Magnoliopsida & Caryophyllales & Amaranthaceae & Gomphrena globosa & & & + \\
\hline 4 & Magnoliopsida & Burserales & Anacardiaceae & Mangifera indica & + & + & \\
\hline 5 & Magnoliopsida & Burserales & Anacardiaceae & Spondias dulcis & + & & + \\
\hline 6 & Magnoliopsida & Annonales & Annonaceae & Annona squamosa & + & & \\
\hline 7 & Magnoliopsida & Magnoliales & Annonaceae & Canangium odoratum & + & + & \\
\hline 8 & Magnoliopsida & Apiales & Apiaceae & Apium graviolens & + & & + \\
\hline 9 & Magnoliopsida & Apiales & Apiaceae & Centella asiatica & & + & \\
\hline 10 & Magnoliopsida & Apocynales & Apocynaceae & Allamanda cathartica & + & + & \\
\hline 11 & Magnoliopsida & Gentilanales & Apocynaceae & Plumeria alba & & + & + \\
\hline 12 & Magnoliopsida & Alismatales & Araceae & Aglaonema commutatum & & & + \\
\hline 13 & Magnoliopsida & Brassicales & Brassicaceae & Brassica rapa & + & & \\
\hline 14 & Magnoliopsida & Caricales & Caricaceae & Carica papaya & + & + & + \\
\hline 15 & Magnoliopsida & Caryophyllales & Basellaceae & Anredera cordifolia & + & & \\
\hline 16 & Magnoliopsida & Caryophyllales & Cactaceae & Coryphantha echinus & + & & \\
\hline 17 & Magnoliopsida & Caryophyllales & Cactaceae & Hylocereus undatus & + & + & \\
\hline 18 & Magnoliopsida & Caryophyllales & Nygtaginaceae & Mirabilis jalapa & & & + \\
\hline 19 & Magnoliopsida & Caryophyllales & Portulacaceae & Portulaca grandiflora & & + & \\
\hline 20 & Magnoliopsida & Cucurbitales & Begoniaceae & Begonia maculata & & + & \\
\hline 21 & Magnoliopsida & Euphorbiales & Euphorbiaceae & Codiaeum variegatum & + & & \\
\hline 22 & Magnoliopsida & Euphorbiales & Euphorbiaceae & Manihot utillissima & + & + & + \\
\hline 23 & Magnoliopsida & Euphorbiales & Euphorbiaceae & Euphorbia milii & & + & \\
\hline 24 & Magnoliopsida & Euphorbiales & Euphorbiaceae & Jatropha podagrica & + & & \\
\hline 25 & Magnoliopsida & Fabales & Fabaceae & Vigna sinensis & & & + \\
\hline 26 & Magnoliopsida & Fabales & Mimosaceae & Parkia speciosa & + & & \\
\hline 27 & Magnoliopsida & Geraniales & Oxalidaceae & Averhoa bilimbi & + & & \\
\hline 28 & Magnoliopsida & Geraniales & Oxalidaceae & Averhoa carambola & & & + \\
\hline 29 & Magnoliopsida & Lamiales & Lamiaceae & Coleus scutellarioides & & & \\
\hline 30 & Magnoliopsida & Lamiales & Lamiaceae & Lavandula angustifolia & + & & + \\
\hline 31 & Magnoliopsida & Malpighiales & Cluceaceae & Garcinia mangostana & + & & \\
\hline 32 & Magnoliopsida & Malpighiales & Phyllanthaceae & Breynia androgyna & + & & + \\
\hline 33 & Magnoliopsida & Malvales & Malvaceae & Hibiscus rosasinensis & + & + & + \\
\hline 34 & Magnoliopsida & Malvales & Malvaceae & Hibiscus sabdariffa & & & + \\
\hline 35 & Magnoliopsida & Myrtales & Myrtaceae & Psidium guajava & + & + & + \\
\hline 36 & Magnoliopsida & Myrtales & Myrtaceae & Syzygium aqueum & & + & \\
\hline 37 & Magnoliopsida & Myrtales & Myrtaceae & Syzigium malaccense & & + & + \\
\hline
\end{tabular}


Tabel 1. Lanjutan

\begin{tabular}{|c|c|c|c|c|c|c|c|}
\hline 1 & 2 & 3 & 4 & 5 & 6 & 7 & 8 \\
\hline 38 & Magnoliopsida & Myrtales & Myrtaceae & Syzygium myrtifolium & & & \\
\hline 39 & Magnoliopsida & Myrtales & Thymelaceae & Phaleriana macrocarpa & + & & + \\
\hline 40 & Magnoliopsida & Oleales & Oleaceae & Jasminum sambac & & & + \\
\hline 41 & Magnoliopsida & Piperales & Piperaceae & Piper betle & + & + & + \\
\hline 42 & Magnoliopsida & Piperales & Piperaceae & Piper nigrum & + & + & \\
\hline 43 & Magnoliopsida & Piperales & Piperaceae & Piper stupposum & + & & \\
\hline 44 & Magnoliopsida & Rosales & Crassulaceae & Kalanchoe pinnata & & & + \\
\hline 45 & Magnoliopsida & Rosales & Moraceae & Arthocarpus heterophyllus & + & & \\
\hline 46 & Magnoliopsida & Rosales & Rosaceae & Rosa hybrida & & + & \\
\hline 58 & Magnoliopsida & Rubiales & Rubiaceae & Gardenia augusta & + & & \\
\hline 47 & Magnoliopsida & Rubiales & Rubiaceae & Ixora chinensis & + & + & + \\
\hline 48 & Magnoliopsida & Rubiales & Rubiaceae & Morinda citrifolia & + & & \\
\hline 49 & Magnoliopsida & Rutales & Rutaceae & Citrus amblycarpa & + & & \\
\hline 50 & Magnoliopsida & Rutales & Rutaceae & Citrus celebica & + & + & \\
\hline 51 & Magnoliopsida & Rutales & Rutaceae & Citrus hystrix & & + & + \\
\hline 52 & Magnoliopsida & Sapindales & Meliaceae & Lansium domesticum & + & + & + \\
\hline 53 & Magnoliopsida & Sapindales & Sapindaceae & Nephelium lappaceum & + & + & \\
\hline 54 & Magnoliopsida & Sapotales & Sapotaceae & Manilkara zapota & + & + & + \\
\hline 55 & Magnoliopsida & Solanales & Convolvulaceae & Ipomoea aquatica & + & & \\
\hline 56 & Magnoliopsida & Solanales & Solanaceae & Capsicum frustescens & + & + & + \\
\hline 57 & Magnoliopsida & Solanales & Solanaceae & Lycopersicum esculentum & + & & + \\
\hline 59 & Magnoliopsida & Solanales & Solanaceae & Physalis angulata & + & & \\
\hline 60 & Magnoliopsida & Solanales & Solanaceae & Solanum torvum & + & + & + \\
\hline 61 & Magnoliopsida & Tubiflorae & Labiatae & Orthisiphon spicatus & & + & \\
\hline 62 & Liliopsida & Alismatales & Araceae & Alocasia macrorrhizos & & + & \\
\hline 63 & Liliopsida & Alismatales & Araceae & Caladium bicolor & + & & + \\
\hline 64 & Liliopsida & Alismatales & Araceae & Colocasia esculenta & + & & \\
\hline 65 & Liliopsida & Alismatales & Araceae & Typhonium flagelliforme & + & & \\
\hline 66 & Liliopsida & Arecales & Arecaceae & Cocos nucifera & + & + & + \\
\hline 67 & Liliopsida & Arecales & Arecaceae & Elaies guineensis & + & & \\
\hline 68 & Liliopsida & Arecales & Arecaceae & Phoenix dactylifera & + & & \\
\hline 69 & Liliopsida & Asparagales & Aloeceae & Aloe vera & + & + & \\
\hline 70 & Liliopsida & Asparagales & Amarylladaceae & Allium fistulosum & & + & \\
\hline 71 & Liliopsida & Asparagales & Asparagaceae & Cordyline fruticosa & + & & \\
\hline 72 & Liliopsida & Asparagales & Asparagaceae & Furcraea foetida & + & & \\
\hline 73 & Liliopsida & Asparagales & Iridaceae & Eleutherine bulbosa & + & & \\
\hline 74 & Liliopsida & Asparagales & Liliaceae & Sansevieria trivasciata & + & + & \\
\hline 75 & Liliopsida & Asterales & Asteraceae & Gynura procumben & + & & \\
\hline 76 & Liliopsida & Bromeliales & Bromeliaceae & Ananas comosus & + & & \\
\hline 77 & Liliopsida & Commelinales & Commelinaceae & Rhoeo discolor & + & + & \\
\hline 78 & Liliopsida & Orchidales & Orchidaceae & Dendrobium bigibbum & & + & \\
\hline 79 & Liliopsida & Pandanales & Pandanaceae & Pandanus amaryllifolius & + & + & + \\
\hline 80 & Liliopsida & Poales & Poaceae & Cymbopogon citrates & + & + & + \\
\hline 81 & Liliopsida & Poales & Poaceae & Saccharum officinarum & & + & \\
\hline 82 & Liliopsida & Poales & Poaceae & Zea mays & + & & \\
\hline 83 & Liliopsida & Zingiberales & Musaceae & Musa acuminata & + & + & \\
\hline 84 & Liliopsida & Zingiberales & Zingiberaceae & Boesenbergia rotunda & + & & \\
\hline 85 & Liliopsida & Zingiberales & Zingiberaceae & Curcuma domestica & + & + & \\
\hline 86 & Liliopsida & Zingiberales & Zingiberaceae & Curcuma mangga & + & & \\
\hline 87 & Liliopsida & Zingiberales & Zingiberaceae & Langua galanga & + & + & + \\
\hline 88 & Cycadopsida & Cycadales & Cycadaceae & Cycas rumpii & + & + & \\
\hline 89 & Gnetopsida & Gnetales & Gnetaceae & Gnetum gnemon & + & & \\
\hline \multicolumn{5}{|c|}{ Jumlah } & 65 & 41 & 32 \\
\hline
\end{tabular}

Kategori pekarangan luas memiliki lebih banyak jumlah jenis tanamannya dibandingkan dengan dua kategori pekarangan lainnya. Pekarangan tersebut memiliki sebanyak 65 jenis tanaman pekarangan yang ada di dalamnya, sedangkan pada pekarangan sedang terdapat 41 jenis tanaman, dan pada pekarangan sempit ditemukan sebanyak 32 jenis tanaman. Persentase ditemukannya tanaman pekarangan pada masingmasing kategori pekarangan dapat dilihat pada Gambar 1. 


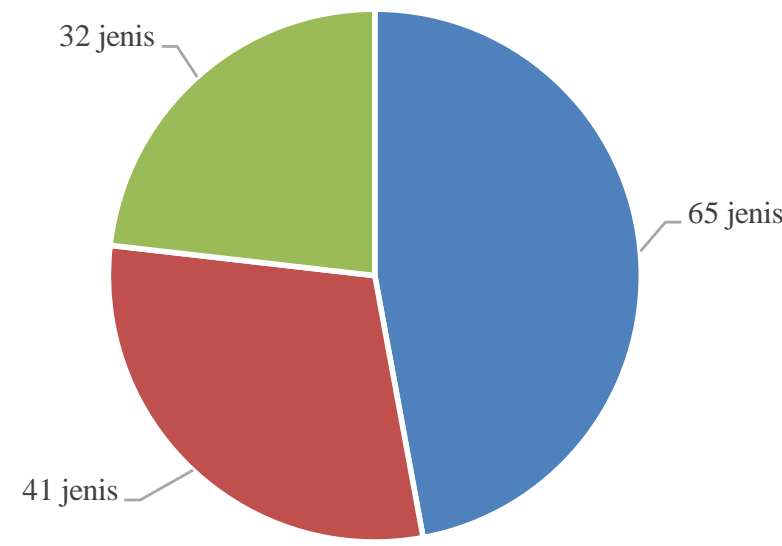

Keterangan:

- Luas

- Sedang

- Sempit

Gambar 1. Pengelompokan Tanaman Pekarangan Berdasarkan Kategori Pekarangan

Kelas Magnoliopsida lebih mendominasi dibandingkan ketiga kelas lainnya yaitu ditemukan sebanyak 61 jenis tanaman atau sebesar $69 \%$, kemudian disusul oleh Kelas Liliopsida yang menjadi kelas kedua terbanyak yaitu 26 jenis tanaman atau sebesar 29\%, sedangkan Kelas Gnetopsida dan Cycadopsida masing-masing ditemukan 1 jenis tanaman sehingga persentase masing-masing kedua kelas tersebut hanya sebesar $1 \%$.

Berdasarkan jumlah dari jenis-jenis tanaman pekarangan yang ada di Desa Tanjung Merpati (Gambar 2) menunjukkan bahwa pada setiap kategori pekarangan terdapat perbedaan jumlah dari jenis-jenis tanaman pekarangan yang ditanam.

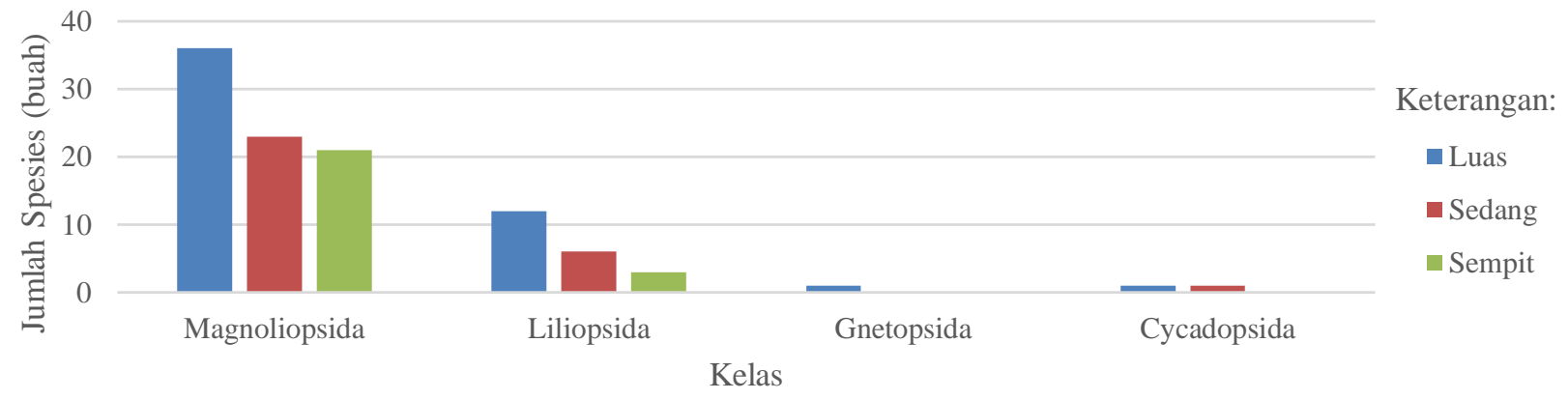

Gambar 2. Pengelompokan Kelas Tanaman Pekarangan pada Tipe Pekarangan Luas, Sedang, dan Sempit

Tipe Pekarangan Luas menjadi pekarangan yang paling banyak dijumpai jenis tanamannya, yaitu sebanyak 65 jenis tanaman yang tergolong dalam 3 kelas yaitu Magnoliopsida sebanyak 40 jenis , Liliopsida sebanyak 22 jenis, Gnetopsida sebanyak 1 jenis dan Cycadopsida dijumpai sebanyak 1 jenis tanaman. Tipe Pekarangan Sedang terdapat 41 jenis tanaman yang tergolong dalam 3 kelas yaitu Kelas Magnoliopsida sebanyak 27 jenis, Liliopsida sebanyak 13 jenis dan Cycadopsida dijumpai sebanyak 1 jenis tanaman. Tipe Pekarangan sempit dijumpai 39 jenis tanaman pekarangan yang tergolong dalam 2 kelas. Jenis yang paling banyak dijumpai berasal dari Kelas
Magnoliopsida sebanyak 31 jenis, dan dari Kelas Liliopsida sebanyak 8 jenis tanaman.

Jenis tanaman yang tergolong dalam Kelas Magnoliopsida lebih banyak ditemukan dibandingkan jenis tanaman pekarangan dari kelas lainnya, baik pada tipe Pekarangan Luas, Sedang maupun Sempit. Kelas Magnoliopsida yang ditemui sebagian besar terdiri dari tanaman buah seperti Nangka (Arthocarpus heterophyllus), Rambutan (Nephelium lappaceum), dan Jambu Biji (Psidium guajava).

Berdasarkan manfaatnya, tanaman pekarangan di Desa Tanjung Merpati terbagi menjadi 5 kelompok, yaitu tanaman hias, tanaman buah, tanaman sayur, tanaman obat dan tanaman 
bumbu. Pengelompokan manfaat tanaman pekarangan ini dapat dilihat pada Tabel 2.

Tabel 2. Pemanfaatan Tanaman Pekarangan di Desa Tanjung Merpati Kecamatan Kembayan Kabupaten Sanggau

\begin{tabular}{|c|c|c|c|c|c|c|c|}
\hline \multirow[b]{2}{*}{ No } & \multirow[b]{2}{*}{ Jenis } & \multirow[b]{2}{*}{ Nama Lokal } & \multicolumn{5}{|c|}{ Manfaat Tanaman } \\
\hline & & & Hias & Buah & Sayur & Obat & Bumbu \\
\hline 1 & 2 & 3 & 4 & 5 & 6 & 7 & 8 \\
\hline 1 & Andrographis paniculata & Sambiloto & & & & + & \\
\hline 2 & Celosia cristata & Jengger Ayam & + & & & & \\
\hline 3 & Gomphrena globosa & Bunga Kancing & + & & & & \\
\hline 4 & Mangifera indica & Mangga & & + & & & \\
\hline 5 & Spondias dulcis & Kedondong & & + & & & \\
\hline 6 & Annona squamosa & Srikaya & & + & & & \\
\hline 7 & Canangium odoratum & Kenanga & + & & & & \\
\hline 8 & Apium graviolens & Seledri & & & & & + \\
\hline 9 & Centella asiatica & Pegagan & + & & & + & \\
\hline 10 & Allamanda cathartica & Bunga Terompet & + & & & & \\
\hline 11 & Plumeria alba & Kamboja & + & & & & \\
\hline 12 & Aglaonema commutatum & Sri Rezeki & + & & & & \\
\hline 13 & Brassica rapa & Sawi & & & + & & \\
\hline 14 & Carica papaya & Pepaya & & + & & & \\
\hline 15 & Anredera cordifolia & Binahong & & & & + & \\
\hline 16 & Coryphantha echinus & Kaktus & + & & & & \\
\hline 17 & Hylocereus undatus & Buah Naga & & + & & & \\
\hline 18 & Mirabilis jalapa & Bunga Terompet Kecil & + & & & & \\
\hline 19 & Portulaca grandiflora & Bunga Kembang Sembilan & + & & & & \\
\hline 20 & Begonia maculata & Begonia Polkadot & + & & & & \\
\hline 21 & Codiaeum variegatum & Puring & + & & & & \\
\hline 22 & Manihot utillissima & Ubi Kayu & & + & + & & \\
\hline 23 & Euphorbia milii & Air mata ibu & + & & & & \\
\hline 24 & Jatropha podagrica & Bunga Guci & + & & & & \\
\hline 25 & Vigna sinensis & Kacang Panjang & & & + & & \\
\hline 26 & Parkia speciosa & Petai & & & + & & \\
\hline 27 & Averhoa bilimbi & Belimbing Wuluh & & & + & & \\
\hline 28 & Averhoa carambola & Belimbing Manis & & + & & & \\
\hline 29 & Coleus scutellarioides & Iler & + & & & & \\
\hline 30 & Lavandula angustifolia & Lavender & + & & & + & \\
\hline 31 & Garcinia mangostana & Manggis & & + & & + & \\
\hline 32 & Breynia androgyna & Cangkok & & & + & & \\
\hline 33 & Hibiscus rosasinensis & Kembang Sepatu & + & & & & \\
\hline 34 & Hibiscus sabdariffa & Rosela & + & & & & \\
\hline 35 & Psidium guajava & Jambu Biji & & + & & & \\
\hline 36 & Syzygium aqueum & Jambu Air & & + & & & \\
\hline 37 & Syzigium malaccense & Jambu Bol & & + & & & \\
\hline 38 & Syzygium myrtifolium & Pucuk Merah & + & & & & \\
\hline 39 & Phaleriana macrocarpa & Mahkota Dewa & + & & & & \\
\hline 40 & Jasminum sambac & Melati & + & & & & \\
\hline 41 & Piper betle & Sirih & & & & + & \\
\hline 42 & Piper nigrum & Sahang & & & + & & \\
\hline 43 & Piper stupposum & Sirih Merah & & & & + & \\
\hline 44 & Kalanchoe pinnata & Cocor Bebek & & & & + & \\
\hline 45 & Arthocarpus heterophyllus & Nangka & & + & & & \\
\hline 46 & Rosa hybrida & Mawar & + & & & & \\
\hline 58 & Gardenia augusta & Kaca Piring & & & & + & \\
\hline 47 & Ixora chinensis & Asoka & + & & & & \\
\hline 48 & Morinda citrifolia & Mengkudu & & & & + & \\
\hline 49 & Citrus amblycarpa & Jeruk Sambal & & + & & & \\
\hline 50 & Citrus celebica & Jeruk Bali & & + & & & \\
\hline 52 & Citrus hystrix & Jeruk Purut & & + & & & \\
\hline 51 & Lansium domesticum & Langsat & & + & & & \\
\hline
\end{tabular}




\begin{tabular}{|c|c|c|c|c|c|c|c|}
\hline 1 & 2 & 4 & 5 & & 7 & 8 & 9 \\
\hline 53 & Nephelium lappaceum & Rambutan & & + & & & \\
\hline 54 & Manilkara zapota & Sawo & & + & & & \\
\hline 55 & Ipomoea aquatica & Kangkung Air & & & + & & \\
\hline 56 & Capsicum frustescen & Cabai Rawit & & & & & + \\
\hline 57 & Lycopersicum esculentum & Tomat & & + & + & & \\
\hline 59 & Physalis angulata & Ciplukan & & + & & & \\
\hline 60 & Solanum torvum & Terong Asam & & & + & & \\
\hline 61 & Orthisiphon spicatus & Kumis Kucing & & & & & \\
\hline 62 & Alocasia macrorrhizos & Bira & + & & & & \\
\hline 63 & Caladium bicolor & Keladi Merah & + & & & & \\
\hline 64 & Colocasia esculenta & Keladi & + & & + & & \\
\hline 65 & Typhonium flagelliforme & Keladi Tikus & + & & & + & \\
\hline 66 & Cocos nucifera & Kelapa & & + & & & \\
\hline 67 & Elaies guineensis & Kelapa Sawit & & + & & & \\
\hline 68 & Phoenix dactylifera & Kurma & & + & & & \\
\hline 69 & Aloe vera & Lidah buaya & + & & & + & \\
\hline 70 & Allium fistulosum & Daun Bawang & & & & & + \\
\hline 71 & Cordyline fruticosa & Andong Merah & + & & & & \\
\hline 72 & Furcraea foetida & Agave & + & & & & \\
\hline 73 & Eleutherine bulbosa & Bawang Dayak & & & & + & \\
\hline 74 & Sansevieria trivasciata & Lidah Mertua & + & & & & \\
\hline 75 & Gynura procumben & Sambung Nyawa & & & & + & \\
\hline 76 & Ananas comosus & Nanas & & + & & & \\
\hline 77 & Rhoeo discolor & Nanas Kerang & + & & & & \\
\hline 78 & Dendrobium bigibbum & Anggrek Ungu & + & & & & \\
\hline 79 & Pandanus amaryllifolius & Pandan Wangi & & & & & + \\
\hline 80 & Cymbopogon citrates & Serai & & & & + & + \\
\hline 81 & Saccharum officinarum & Tebu & & + & & & \\
\hline 82 & Zea mays & Jagung & & + & + & & \\
\hline 83 & Musa acuminata & Pisang Mas & & + & & & \\
\hline 84 & Boesenbergia rotunda & Temu Kunci & & & & + & \\
\hline 85 & Curcuma domestica & Kunyit & & & & & + \\
\hline 86 & Curcuma mangga & Kunyit Putih & & & & + & \\
\hline 87 & Langua galanga & Lengkuas & & & & & + \\
\hline 88 & Cycas rumpii & Pakis Aji & + & & & & \\
\hline 89 & Gnetum gnemon & Melinjo & & & + & & \\
\hline \multicolumn{3}{|c|}{ Jumlah } & 34 & 27 & 13 & 17 & 7 \\
\hline
\end{tabular}

Tanaman hias ditemukan paling banyak di Desa Tanjung Merpati, yaitu sebanyak 34 jenis tanaman dan tanaman buah menempati tempat kedua terbanyak yaitu ditemukan sebanyak 27 jenis tanaman. Tanaman obat diurutan ketiga terbanyak setelah tanaman hias dan buah, yaitu ditemukan sebanyak 17 jenis tanaman, sedangkan tanaman sayur dan bumbu masing-masing ditemukan sebanyak 13 dan 7 jenis tanaman. Persentase pemanfaatan tanaman pekarangan di desa tersebut dapat dilihat pada Gambar 3.

Gambar 3 menunjukkan bahwa Tanaman Hias lebih mendominasi dengan persentase ditemukan sebesar $34 \%$ dari total keseluruhan ditemukannya tanaman pekarangan, kemudian disusul oleh Kelompok Tanaman Buah yaitu sebesar 27\%. Tanaman Obat menempati posisi terbanyak ketiga dengan persentase ditemukan sebesar 17\%, serta Tanaman Sayur dan Bumbu dengan persentase ditemukannya masing-masing sebesar $13 \%$ dan $9 \%$.

\section{Pembahasan}

Jenis tanaman pekarangan dari kelas Magnoliopsida lebih banyak ditemukan dibandingkan jenis tanaman dari kelas lainnya, hal ini dikarenakan jenis-jenis tanaman dari kelas tersebut umumnya memiliki manfaat cukup besar bagi masyarakat setempat. Tanaman dari Kelas Magnoliopsida umumnya tergolong jenis tanaman buah, hias dan sayuran. Tanaman buah contohnya Sawo (Manilkara zapota) dan Manggis (Garcinia mangostana), tanaman hias contohnya Bunga Terompet (Allamanda cathartica) dan Kumis Kucing (Orthisiphon spicatus), serta sayuran contohnya Terong Asam (Solanum torvum) dan 
Tomat (Lycopersicum esculentum). Banyaknya jenis-jenis tanaman dari Kelas Magnoliopsida yang diperoleh didukung oleh hasil penelitian Andriansyah (2015) bahwa Kelas Magnoliopsida memiliki jumlah spesies terbanyak yaitu 57 jenis, dan Kelas Liliopsida memiliki jumlah spesies terbanyak kedua setelah Kelas Magnoliopsida, yaitu 18 jenis.

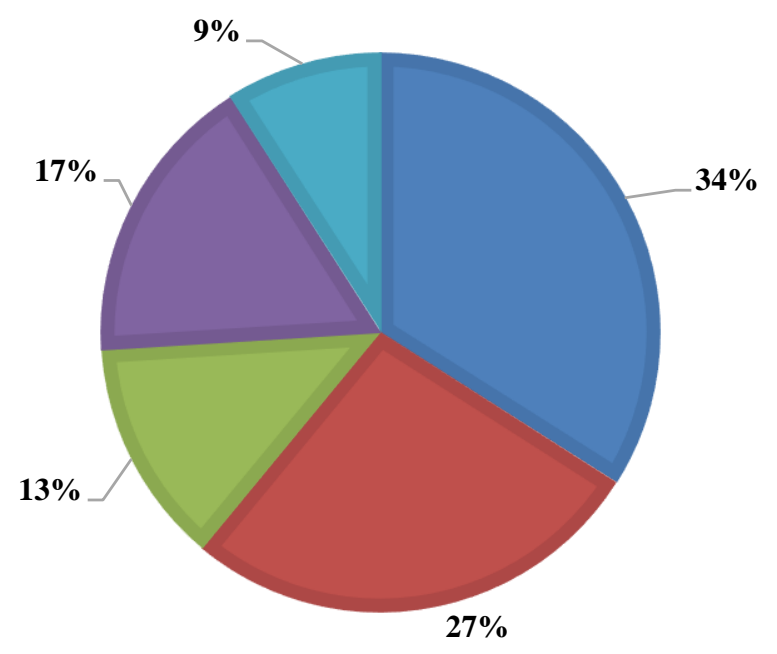

Keterangan:

- Hias

- Buah-buahan

- Sayuran

-Obat

- Bumbu

Gambar 3. Pemanfaatan Tanaman Pekarangan di Desa Tanjung Merpati Kecamatan Kembayan Kabupaten Sanggau

Jenis tanaman dari kelas Liliopsida menempati posisi terbanyak kedua yang ditanam masyarakat. Tanaman dari kelas tersebut terdiri dari tanaman hias contohnya Keladi Merah (Caladium bicolor) dan Lidah Buaya (Aloe vera), tanaman buah contohnya Kelapa (Cocos nucifera) dan Kurma (Phoenix dactylifera), tanaman obat contohnya Serai (Cymbopogon citrates) dan Kunyit Putih (Curcuma mangga), dan tanaman bumbu contohnya Kunyit (Curcuma domestica) dan Lengkuas (Langua galanga).

Pekarangan luas di Desa Tanjung Merpati memiliki jumlah jenis tanaman yang paling banyak. Warga yang memiliki pekarangan luas cenderung menanam tanaman pohon penghasil buah seperti Kelapa Muda (Cocos nucifera), Rambutan (Psidium guajava), dan Nangka (Arthocarpus heterophyllus). Tanaman dengan ukuran dan diameter batang yang besar seperti ini sangat cocok ditanam pada Pekarangan Luas. Hal ini sesusai dengan hasil penelitian Pendong (2004) yang menyatakan bahwa, adanya kesesuaian dan keseimbangan dalam hal pemanfaatan lahan yaitu antara ketersediaan lahan (dan ruang) dengan pemilihan tanaman yang digunakan. Pemanfaatan lahan pekarangan oleh penduduk untuk budidaya tanaman yang sesuai dengan bentuk pertumbuhan dan fungsinya di pekarangan, menunjukkan penduduk dalam memanfaatkan pekarangannya telah memperhatikan keseimbangan tata ruang secara alamiah serta efisiensi pemanfaatannya.
Secara umum Masyarakat Desa Tanjung Merpati telah memanfaatkan lahan pekarangannya sebagai sumber pemenuhan kebutuhan, baik untuk memenuhi kebutuhan pangan, obat, maupun rasa estetikanya. Hal ini menunjukkan bahwa lahan pekarangan yang ada memiliki peranan cukup besar dalam kehidupan warga. Hal ini sesuai dengan pernyataan Watson dan Eyzaguire (2002) dalam Budiadi et al (2015), bahwa lahan pekarangan memiliki fungsi multiguna, karena dari lahan yang relative sempit dapat menghasilkan bahan pangan seperti umbi-umbian, sayur, buah-buahan, bahan tanaman rempah dan obat, bahan kerajinan tangan, bahan pangan hewani yang berasal dari unggas ternak kecil maupun ikan, tanaman hias, bahan bangunan, kayu bakar, dan pakan ternak.

Tanaman hias merupakan tanaman yang paling banyak ditanam di pekarangan, yaitu sebanyak 30 jenis atau sebesar $39 \%$ dari keseluruhan tanaman yang ditemukan. Jenis tanaman tersebut yang banyak dijumpai di Desa Tanjung Merpati yaitu Lidah Mertua (Sansevieria trivasciata), Puring (Codiaeum variegatum), Bunga Terompet (Allamanda cathartica), dan Asoka (Ixora chinensis). Tanaman Lidah Mertua (Sansevieria trivasciata) dan Puring (Codiaeum variegatum) biasanya ditanam warga pada bagian tepi pekarangan, sebagai pembatas antara pekarangan warga yang satu dengan yang lainnya (Lampiran 6). 
Banyaknya jenis tanaman hias yang ditanam di pekarangan warga menunjukkan bahwa masyarakat Desa Tanjung Merpati cukup memperhatikan keindahan lingkungan sekitar rumahnya. Hal ini didukung oleh penelitian Sihombing (2008) yang menyatakan bahwa tinggi nya keberadaan dari kelompok tanaman hias (37\%) pada pekaranga penduduk di Kecamatan Delta Pawan menunjukkan kesadaran akan pentingnya nilai keindahan yang diperoleh dari penanaman berbagai jenis tanaman hias di pekarangan oleh penduduk cukup tinggi.

Tanaman terbanyak kedua yang ditanam di pekarangan adalah tanaman penghasil buah yaitu sebanyak 28 jenis atau sebesar 30\%. Jenis tanaman buah yang banyak dijumpai yaitu Buah Naga (Hylocereus undatus), Pepaya (Carica papaya), Sawo (Manilkara zapota) dan Rambutan (Nephelium lappaceum). Banyaknya tanaman buah yang dijumpai dipengaruhi oleh kecenderungan warga yang suka mengonsumsi buah dari tanaman tersebut, selain itu buah hasil panen dari tanaman. ini juga mudah dipasarkan dan cukup banyak peminatnya. Andriansyah (2016) juga menyatakan bahwa pekarangan merupakan lingkungan buatan, sehingga tanaman cenderung sengaja ditanami dengan keinginan pemilik pekarangan.

Tanaman sayur dan bumbu yang ditemukan memiliki jumlah jenis yang hampir sama, yaitu masing-masing 10 jenis (11\%) dan 9 jenis (10\%) tanaman. Tanaman sayur yang banyak dijumpai yaitu Cangkok (Breynia androgyna) dan Terong Asam (Solanum torvum), sadangkan tanaman bumbu yang banyak jumpai yaitu Cabai rawit (Capsicum frustescens) dan Serai (Cymbopogon citrates). Adanya tanaman sayuran dan bumbu di pekarangan sangat membantu warga dalam pemenuhan kebutuhan pangan sehari-hari. Kesadaran warga akan kebutuhan ekonomi yang semakin meningkat setiap harinya, mendorong warga untuk menanam tanaman sayur dan bumbu di pekarangan, sehingga dapat menekan jumlah pengeluaran sehari-hari khususnya untuk kebutuhan memasak. Watson dan Eyzaguire (2002) dalam Budiadi et al (2015), juga menyatakan bahwa manfaat yang akan diperoleh dari pengelolaan pekarangan antara lain dapat memenuhi kebutuhan konsumsi dan gizi keluarga, menghemat pengeluaran dan juga dapat memberikan tambahan pendapatan bagi keluarga.

Tanaman obat di Desa Tanjung Merpati ditemukan sebanyak 16 jenis atau sebesar $17 \%$ dari keseluruhan jumlah tanaman yang ditemukan, diantaranya yaitu Daun sirih (Piper betle), dan Serai (Cymbopogon citrates). Tanaman serai selain dimanfaatkan sebagai bumbu masakan, juga dimanfaatkan warga sebagai obat penghilang bau badan, yaitu dengan merebus batang serai dan meminum air rebusannya setiap pagi 1 kali dalam sehari. Selain itu ada juga warga yang percaya dengan menanam serai disekitaran rumah dapat mencegah banyak nya nyamuk berkeliaran disekitar rumah. Hal ini didukung dengan hasil penelitian Sastriawan (2014), bahwa ekstrak serai dapur (Cymbopogon citrates) efektif sebagai larvasida terhadap larva Aedes sp., ditemukan kematian sebanyak 50\% larva pada konsentrasi ekstrak 312,5 ppm, dan kematian sebesar $90 \%$ pada konsentrasi $2500 \mathrm{ppm}$.

\section{DAFTAR PUSTAKA}

Andriansyah SN, Lovadi I, Linda R, 2015, Keanekaragaman Jenis Tanaman Pekarangan di Desa Antibar Kecamatan Mempawah Timur Kabupaten Mempawah, Jurnal Protobiont, Vol. 4 (1) : 226-235

Arifin HS, 2013, Pekarangan Kampung untuk Konservasi Agro-Biodiversitas dalam Mendukung Penganekaragaman dan Ketahanan Pangan di Indonesia, Fakultas Pertanian IPB, Bogor

Danoesastro H, 1978, Perananan Pekarangan dalam Usaha Meningkatkan Ketahanan Nasional Rakyat Pedesaan, Agro-Ekonomi UGM, Yogyakarta

Fachrul M, 2006, metode Sampling Bioekologi, Bumi Aksara, Jakarta

Kurnianingsih A, Nusyirwan, Setyadi ED, Syawal Y, 2013, Optimalisasi Lahan Pekarangan dengan Budidaya Tanaman Lidah Buaya yang Berkhasiat Obat di Desa Purna Jaya Kecamatan Indralaya Kabupaten Ogan Ilir, Jurnal Pengabdian Sriwijaya, fakultas Pertanian Universitas Sriwijaya

Lathifah SS, Rahmaniah R, Yuliani R, Rosari RN, Fathurrahman A, 2015, Keanekaragaman Tumbuhan di Hutan Evergreen Taman Nasional Baluran Situbondo Jawa Timur, Prosiding Semirata 2015 bidang MIPA BKS-PTN Barat, Universitas Tanjungpura Pontianak, Hal 123-134

Menteri Pertanian Republik Indonesia, 2016, Petunjuk Teknis Gerakan Percepatan Penganekaragaman Konsumsi Pangan, Keputusan Menteri Pertanian Republik Indonesia, No 12/KPTS/KN.210/K/02/2016

Mukarlina, Linda R, Nurlaila N, 2012, Keanekaragaman Jenis Tanaman Pekarangan di Desa Pahauman 
Kecamatan Sengah Temila Kabupaten Landak, Kalimantan Barat, Saintifica, Vol. 16 (1) : 51-62

Njurumana GN, Marsono D, Irham, Sadono R, 2014, Konservasi Keanekaragaman Hayati Tanaman pada Sistem Kaliwu di Pulau Sumba, Jurnal Manusia dan Lingkungan, Vol. 21 (1) : 75-82

Nurwati N, Lidar S, Mufti, 2015, Model Pemberdayaan Pekarangan di Kecamatan Rumbai Pesisir Kota Pekanbaru, Jurnal Agribisnis, Vol. 17 (1)

Odum EQ, 1993, Dasar-Dasar Ekologi, Edisi Ketiga, Gadjah Mada University Press, Yogyakarta

Paulina A, 2005, Upaya Peningkatan Pendapatan Petani Melalui Program Pemanfaatan Lahan Pekarangan di desa Sirang Setambang Kecamatan Sepauk Kabupaten Sintang, Skripsi, Fakultas Pertanian, Universitas Tanjungpura, Pontianak

Pendong DF, Aprijani, 2004, Keanekaragaman Tanaman Pekarangan di Kota Tomohon, Sulawesi Utara, Jurnal Biosmart, Jurusan Biologi FMIPA Universitas Sebelas Maret Surakarta, Vol. 6 (1) : 44-50

Rahayu M, Prawiroatmodjo S, 2005, Keanekaragaman Tanaman Pekarangan dan Pemanfaatannya di Desa Lampaepi, Pulau Wawoni - Sulawesi Tenggara, Jurnal Teknologi Lingkungan, Vol. 6 (2) : 360-364

Rukmana HR, 2005, Teknik Perbanyakan Tanaman Hias, Kanisius, Yogyakarta

Sihombing DS, 2008, Keanekaragaman Jenis Tanaman Pekarangandi Kecamatan Delta Pawan Kabupaten Ketapang, Skripsi, fakultas Matematika dan Ilmu Pengetahuan Alam Universitas Tanjungpura, Pontianak

Soerianegara I, Indrawan A, 1980, Ekologi Hutan Indonesia, Fakultas Kehutanan Institut Pertanian Bogor, Bogor

Steenis CGGJ, 2005, Flora, PT.Pradnya Paramita, Jakarta

Suin NM, 2002, Metode Ekologi Universitas Andalas, Padang

Sulardi, 2010, Tingkat Kerapatan dan Pola Pemetaan Tanamamn Pekarangan di Kecamatan Kaliwungu Kabupaten Semarang Jawa Tengah, Skripsi, Universitas Muhammadiyah, Surakarta

Sutoyo, 2010, Keanekaragaman Hayati Indonesia, Buana Sains, Program Studi Agroteknologi Fakultas
IPSA Universitas Tribhuwana Tunggadewi, Vol. 10 (2) : 101-106

Tjitrosoepomo G, 2002, Taksonomi Tumbuhan (Spermatophyta), Gadjah Mada University Press, Yogyakarta 